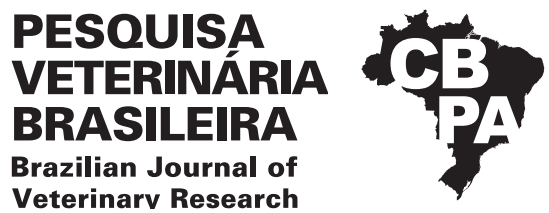

Pesq. Vet. Bras. 41: e06713, 2021

DOI: 10.1590/1678-5150-PVB-6713

Original Article

Veterinarv Research

ISSN 0100-736X (Print)

Wildlife Medicine

ISSN 1678-5150 (Online)

\title{
Ultrasonographic characterization of the organs in the middle third and caudal coelomic cavity of snakes in the Boidae family ${ }^{1}$
}

\author{
Nathana B. Martins ${ }^{2 *}$ (D), Lucas A.R. Ferreira², Nataly N.R. Pinto², \\ Christina S. Mendonça ${ }^{3}$, Liria Q.L. Hirano ${ }^{4}$, André Santos A.L.Q ${ }^{2}$ \\ and Vanessa M.F. Milken ${ }^{3}$
}

\begin{abstract}
Martins N.B., Ferreira L.A.R., Pinto N.N.R., Mendonça C.S., Hirano L.Q.L., Santos A. \& Milken V.M.F 2021. Ultrasonographic characterization of the organs in the middle third and caudal coelomic cavity of snakes in the Boidae family. Pesquisa Veterinária Brasileira 41:e06716, 2021. Laboratório de Ensino e Pesquisa em Animais Silvestres, Universidade Federal de Uberlândia, Rua Piauí s/n, Bairro Umuarama, Uberlândia, MG 38400-902, Brazil. E-mail: nathanabmartins@gmail.com

The aim of this study was the ultrasonographic evaluation of the organs in the middle third and caudal coelomic cavity of healthy snakes in the Boidae family. For such, 15 adult snakes from five species were evaluated: Boa constrictor amarali, Boa constrictor constrictor, Eunectes murinus, Epicrates assisi and Epicrates crassus. The animals were physically restrained for examination. After the application of acoustic gel over the scales the transducer was positioned in the frontal plane of the coelomic cavity. Microconvex and linear transducers at $10 \mathrm{MHz}$ were used. The ultrasound examination was conducted in the craniocaudal direction, with longitudinal and transversal sections to assess syntropy, echogenicity and echotexture of the organs. The liver was bilobulated, hyperechoic, homogeneous echotexture, hyperechoic capsule, with a hepatic lobe measuring $1.15 \pm 0.64 \mathrm{~cm}$ wide, and the presence of a central hepatic vein, measuring $0.44 \pm 0.21 \mathrm{~cm}$ in diameter. The gallbladder was characterized as an anechoic structure with echogenic walls and dimensions of $2.91 \pm 1.18 \mathrm{~cm} \times 1.38 \pm 0.84 \mathrm{~cm}$ (length $\mathrm{x}$ width). The stomach showed a pleated and linear texture, echogenic, with hypoechoic walls measuring $0.3 \pm 0.07 \mathrm{~cm}$ wide. The splenopancreas was a circular and echogenic structure, homogeneous echotexture and measuring $1.18 \pm 0.62 \mathrm{~cm}$ in width and $1.56 \pm 0.88 \mathrm{~cm}$ in length. The kidneys were characterized by elongated, lobulated, hypoechoic structures, an echogenic capsule and an echogenic central line, measuring $1.05 \pm 0.7 \mathrm{~cm}$ in width. The testis were characterized by fusiform, hypoechoic structures, homogeneous echotexture, measuring $2.31 \pm 0.79 \mathrm{~cm}$ in length and $0.6 \pm 0.23 \mathrm{~cm}$ in width. Ovarian follicles were seen in different stages, $0.67 \pm 0.39 \mathrm{~cm}$ wide and $0.73 \pm 0.38 \mathrm{~cm}$ long. No differences were found between species of syntropy, echogenicity and echotexture of the organs of the coelomic cavity. The ultrasound examination proved to be a safe, non-invasive and efficient technique for characterizing the organs of the coelomic cavity of snakes.
\end{abstract}

INDEX TERMS: Ultrasonography, coelomic cavity, snakes, Boidae family, Boa constrictor, Epicrates spp., Eunectes murinus, diagnostic imaging, Squamata, wildlife animals.

\footnotetext{
${ }^{1}$ Received on May 28, 2020.

Accepted for publication on November 2, 2020.

${ }^{2}$ Laboratório de Ensino e Pesquisa em Animais Silvestres, Universidade Federal de Uberlândia (UFU), Rua Piauí s/n, Bairro Umuarama, Uberlândia, MG 38400-902, Brazil. *Corresponding author: nathanabmartins@gmail.com

${ }^{3}$ Setor de Diagnóstico por Imagem, Hospital Veterinário, Universidade Federal de Uberlândia (UFU), Av. Mato Grosso 3289, Bloco 2S, Umuarama, Uberlândia, MG 38405-314, Brazil.

${ }^{4}$ Hospital Veterinário de Pequenos Animais, Faculdade de Agronomia e Medicina Veterinária, Universidade de Brasília (UnB), Campus Universitário Darcy Ribeiro, Av. L4 Norte, Setor de Clubes Norte, Brasília, DF 70910-900, Brazil.
}

RESUMO.- [Caracterização ultrassonográfica dos órgãos do terço médio e caudal da cavidade celomática de serpentes da família Boidae.] 0 objetivo do estudo foi realizar a avaliação ultrassonográfica de órgãos do terço médio e caudal da cavidade celomática de serpentes hígidas da família Boidae. Para isto, foram avaliadas 15 serpentes adultas de cinco espécies: Boa constrictor amarali, Boa constrictor constrictor, Eunectes murinus, Epicrates assisi e Epicrates crassus. Os animais foram contidos fisicamente para a realização do exame. Após 
aplicação de gel acústico sobre as escamas, o transdutor foi posicionado no plano frontal da cavidade celomática. Foram utilizados transdutores microconvexo e linear em $10 \mathrm{MHz} .0$ exame ultrassonográfico foi conduzido no sentido craniocaudal, com cortes longitudinais e transversais para avaliar sintopia, ecogenicidade e ecotextura dos órgãos. 0 fígado se apresentou bilobulado, hiperecoico, ecotextura homogênea, cápsula hiperecoica, com lobo hepático medindo 1,15 $\pm 0,64 \mathrm{~cm}$ de largura, e presença de uma veia central hepática, medindo $0,44 \pm 0,21 \mathrm{~cm}$ de diâmetro. A vesícula biliar foi caracterizada como uma estrutura anecoica de paredes ecogênicas e dimensões de $2,91 \pm 1,18 \mathrm{~cm} \times 1,38 \pm 0,84 \mathrm{~cm}$ (comprimento $\mathrm{x}$ largura). 0 estômago apresentou-se com o aspecto pregueado e linear, ecogênico, com paredes hipoecoicas medindo $0,3 \pm 0,07 \mathrm{~cm}$ de largura. 0 esplenopâncreasse apresentou como uma estrutura circular e ecogênica, ecotextura homogênea e medindo de $1,18 \pm 0,62 \mathrm{~cm}$ de largura e $1,56 \pm 0,88 \mathrm{~cm}$ de comprimento. Os rins se caracterizaram por estruturas alongadas, lobuladas, hipoecoicas, cápsula ecogênica e uma linha central ecogênica, medindo $1,05 \pm 0,7 \mathrm{~cm}$ de largura. 0 s testículos foram caracterizados por estruturas fusiformes,

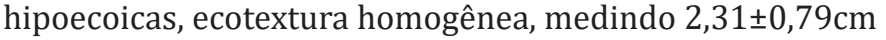
de comprimento e $0,6 \pm 0,23 \mathrm{~cm}$ de largura. Foram visualizados folículos ovarianos em diferentes estágios, de $0,67 \pm 0,39 \mathrm{~cm}$ de largura e $0,73 \pm 0,38 \mathrm{~cm}$ de comprimento. Não foram encontradas diferenças entre espécies de sintopia, ecogenicidade e ecotextura dos órgãos da cavidade celomática. 0 exame ultrassonográfico demonstrou-se uma técnica segura, não invasiva e eficiente para caracterização dos órgãos da cavidade celomática de serpentes.

TERMOS DE INDEXAÇÃO: Ultrassonografia, cavidade celomática, serpentes, Boidae, boídeos, celoma, diagnóstico por imagem, ofídios, animais selvagens.

\section{INTRODUCTION}

With the growing demand to assist wild and exotic animals in veterinary medicine, the anatomical knowledge is extremely important to elaborate the diagnosis and for the success in choosing a therapeutic protocol (Bortolini et al. 2013). Ultrasound, as well as radiography, are noninvasive diagnostic imaging techniques largely used in the veterinary practice (Muzzi et al. 2001). The success of the examination will depend on variables such as anatomical knowledge of the species and the ability and experience of the operator (Oliveira et al. 2013).

The diagnostic imaging, although largely used, is still a challenge in reptile medicine due to the scarcity of normality parameters, mainly when dealing with animals of the Brazilian fauna (Bortolini et al. 2012, Augusto \& Hildebrandt 2014). Thus, anatomical studies are necessary in healthy animals to characterize and standardize the normality references of the organs (Bortolini et al. 2012).

Several snake species in the Boidae family are raised in captivity by zoos, breeders, collectors and tutors (Banzato et al. 2012). However, there is little literature in studies that evaluate the coelomic cavity of snakes in this family through ultrasound. Researches were reported on Boa constrictor to evaluate the liver, spleen and urogenital tract (Andrade et al. 2012), on Eunectes murinus, Boa constrictor constrictor, Corallus hortulanus and Epicrates cenchria evaluating the reproductive organ (Garcia et al. 2015) and on Boa constrictor imperator evaluating the organs in the coelomic cavity (Banzato et al. 2012). No studies were found in the species Boa constrictor amarali, Epicrates assisi and Epicrates crassus, making this work the first of its kind.

Therefore, the aim of the present study was to characterize the organs in the middle third and caudal coelomic cavity of healthy snakes in the Boidae Family through ultrasound, such as $B$. constrictor amarali, B. constrictor constrictor, E. murinus, E. assisi and E. crasus.

\section{MATERIALS AND METHODS}

The research was authorized under protocol 037/2018 from the Committee for the Ethics in Animal Use (CEUA) at the "Universidade Federal de Uberlândia" (UFU), and Biodiversity Authorization and Information System (SISBIO) under protocol 62659. The study was done in the months of August and September 2019.

Fifteen adult animals from the Boidae family were used, coming from the "Laboratório de Ensino e Pesquisa em Animais Silvestres" (LAPAS-UFU), of these, one Boa constrictor constrictor, one Eunectes murinus, three Epicrates assisi, three Epicrates crassus and seven Boa constrictor amarali. Upon physical examination all animals were healthy.

The animals were identified, weighed, sexed and the cloacal rostrum length was measured with a $1.5 \mathrm{~m}$ measuring tape. The identification was done with numbered tags in plastic individual organization boxes, where the animals stayed during the study. The weight was measured with a digital scale.

Sexing was done through the introduction of a lubricated edge probe in the cloaca, in the caudal direction, and confirmed through ultrasound examination. Animals in which the probe passed 8 to 12 sub-caudal scales were considered male, and when the probe passed only two to four sub-caudal scales the specimen was considered female. There was a total of six females and nine males. The corporal mass and rostrum-cloacal length of each species are described in Table 1.

The snakes were kept under fasting for seven days previous to the ultrasound examination. The animals were physically restrained with a herpetological hook and then manually contained for approximately ten minutes for ultrasonographic evaluation. They stayed in an anatomical position and a layer of water-soluble gel was applied on the windows to allow the transmission of ultrasonic waves in the transducer contact with the scales. The acoustic window was obtained through the frontal plane and the scan was done in the craniocaudal direction through a GE Logiq $\mathrm{F} 6{ }^{\circledR}$ device, a real time bidimensional equipment. The frequency choice $(5-10 \mathrm{MHz})$ and shape of the transducer (microconvex or linear) varied according to the size of the animals.

The coelomic cavity was divided in three thirds and the scan was done in the craniocaudal direction of the middle and caudal third. The beginning of the evaluation was marked by a cardiac and large vessel image, which serves as anatomical reference for the cranial limit of the liver. All structures were evaluated in sagittal and transversal planes.

Morphology, syntropy, echogenicity and echotexture of the liver, gallbladder, stomach, intestinal loops, kidneys, testis and ovarian follicles were evaluated andmeasured.

The ultrasonographic exam and measurements of the organs were done by a single operator. The images obtained through ultrasound were evaluated for reference description and comparison among species in the study.

A simple descriptive statistical analysis, with average and standard deviation of organ dimensions was done in Excel. 


\section{RESULTS}

There were no differences among species regarding syntropy, morphology, echogenicity and echotexture of the evaluated organs. However, for measurement of the organs in the coelomic cavity, the animals were separated in species due to variations in corporal mass. The dimension of the organs is represented in Table 2.

The liver was located and evaluated in the sagittal plane, right after the end of the cranial third and beginning of the middle third of the animal, in a caudal position to the heart apex. The organ was bilobulated, with echogenicity varying from hypoechoic in relation to the splenopancreas and slightly hyperechoic in relation to the kidney, with homogeneous echotexture, surrounded by a hyperechogenic capsule and with the presence of a tubular structure, with hyperechoic walls, and anechogenic content, characterizing the hepatic vein (Fig.1).

The gallbladder (GB) was evaluated in the longitudinal and transverse planes, was not directly connected to the liver and was located on the right side, caudal to the stomach and cranial to the spleen and pancreas, at the end of the animal's middle third. It presented itself as a structure of anechogenic content and echogenic wall (Fig.1). It was not possible to see the bile duct.

The stomach was located dorsal to the liver and cranial to the GB, halfway through middle third of the animal. It was elongated, pleated, linear, echogenic with the hypoechoic walls and heterogeneous echotexture, in the longitudinal and transverse planes (Fig.1). In some animals, the organ was found without content and in others with food content and gases.

The intestine was located caudal to the stomach, in the middle and caudal third of the coelomic cavity. The organ was evaluated in the longitudinal and transversal planes, but it was not possible to delimit the organ contours in most animals, due to the presence of gases, faeces or food content in its lumen, therefore, the organ was not measured. It was seen only in one specimen of Epicrates crassus, in the specimen of Eunectes murinus and in a Boa constrictor amarali snake.

The spleen and pancreas were visualized as a single structure, called splenopancreas in all species, located caudally to the GB, in the end of the middle third of the animal. The spleen was characterized by a small, circular structure, hyperechoic with respect to the liver, homogeneous echotexture and surrounded by a hyperechoic capsule. The pancreas was slightly hypoechogenic in relation to the spleen with homogeneous echotexture (Fig.2). It was not possible to see it in all animals.

The kidneys were seen in the caudal third of the coelomic cavity in the longitudinal plane, with the right kidney located more cranial than the left. They were characterized by an elongated, lobulated structure, hypoechoic in relation to the liver and splenopancreas, heterogeneous echotexture, surrounded by a hyperechoic capsule, with the central region of minor echogenicity and an echogenic central line. The cortical

Table 1. Body mass, in kilograms (kg), and rostro-cloacal length (CRC) in centimeters (cm), of snakes of the Boidae family from the "Laboratório de Ensino e Pesquisa em Animais Silvestres" of the "Universidade Federal de Uberlândia"

\begin{tabular}{|c|c|c|c|c|c|c|}
\hline \multirow{2}{*}{ Species } & \multicolumn{2}{|c|}{ Weight (kg) } & \multicolumn{2}{|c|}{ CRC $(\mathrm{cm})$} & \multicolumn{2}{|c|}{ Sexing (N) } \\
\hline & minimum & maximum & minimum & maximum & Male & Female \\
\hline Boa constrictor amarali & 1.058 & 2.046 & 102 & 153 & 2 & 5 \\
\hline Epicrates crassus & 0.600 & 0.650 & 102 & 104 & 2 & 1 \\
\hline Eunectes murinus & \multicolumn{2}{|c|}{12} & \multicolumn{2}{|c|}{245} & 0 & 1 \\
\hline
\end{tabular}

Table 2. Measurement, in centimeters, of the organs of the middle and caudal thirds of the coelomic cavity of snakes of the Boidae family. The minimum (Min) and maximum (Max) measurements were obtained for each species, and the mean (M) and standard deviation (SD) were obtained for all species in general

\begin{tabular}{|c|c|c|c|c|c|c|c|c|c|}
\hline & \multicolumn{2}{|c|}{$\begin{array}{l}\text { Epicrates assisi } \\
\qquad(\mathrm{n}=3)\end{array}$} & \multicolumn{2}{|c|}{$\begin{array}{l}\text { Epicrates crassus } \\
(\mathrm{n}=3)\end{array}$} & \multicolumn{2}{|c|}{$\begin{array}{l}\text { Boa constrictor amarali } \\
(\mathrm{n}=7)\end{array}$} & \multirow{2}{*}{$\begin{array}{l}\text { Boa constrictor } \\
\text { constrictor } \\
(\mathrm{n}=1)\end{array}$} & \multirow{2}{*}{$\begin{array}{l}\text { Eunectes murinus } \\
\qquad(\mathrm{n}=1)\end{array}$} & \multirow{2}{*}{$\begin{array}{c}\text { General }(\mathrm{n}=15) \\
\mathrm{M} \pm \mathrm{SD}\end{array}$} \\
\hline & Min & Max & Min & Max & Min & Max & & & \\
\hline HL & 0.57 & 1.61 & 0.39 & 0.84 & 0.64 & 1.81 & 1.23 & 2.16 & $1.15 \pm 0.64$ \\
\hline HV & 0.39 & 0.83 & 0.26 & 0.30 & 0.26 & 0.71 & 0.42 & 0.40 & $0.44 \pm 0.21$ \\
\hline GBL & 2.6 & 4.53 & 1.58 & 2.17 & 1.36 & 3.9 & 4.11 & 3.06 & $2.91 \pm 1.18$ \\
\hline GBW & 0.92 & 1.22 & 0.5 & 0.74 & 0.95 & 2.98 & 1.4 & 2.41 & $1.38 \pm 0.84$ \\
\hline SW & 0.23 & 0.39 & 0.22 & 0.27 & 0.24 & 0.39 & 0.31 & 0.4 & $0.3 \pm 0.07$ \\
\hline $\mathrm{KW}$ & 0.94 & 1.24 & 0.31 & 2.5 & 0.85 & 1.46 & 0.77 & 0.36 & $1.05 \pm 0.7$ \\
\hline SPW & 0.88 & 1.27 & - & - & 0.62 & 0.92 & 2.21 & - & $1.18 \pm 0.62$ \\
\hline SPL & 0.95 & 2.88 & - & - & 0.71 & 2.0 & 1.27 & - & $1.56 \pm 0.88$ \\
\hline ow & - & - & 0.35 & 0.36 & 0.81 & - & 1.18 & - & $0.67 \pm 0.39$ \\
\hline $\mathrm{OL}$ & & & 0.37 & 0.44 & 1.02 & - & 1.11 & - & $0.73 \pm 0.38$ \\
\hline TW & 0.52 & 1.0 & 0.59 & - & 0.41 & 0.48 & - & - & $0.6 \pm 0.23$ \\
\hline $\mathrm{TL}$ & 1.77 & 3.7 & 1.92 & - & 1.95 & 2.21 & - & - & $2.31 \pm 0.79$ \\
\hline
\end{tabular}

(-) not shown, GBW = gallbladder (width), GBL = gallbladder (length), HL = hepatic lobe (width), HV = hepatic vein (width), KW = kidney (width), $\mathrm{OL}=$ ovarian follicles (length), OW = ovarian follicles (width), SW = stomach wall (width), SPL = splenopancreas (length), SPW = splenopancreas (width), $\mathrm{TL}=$ testicle (length), $\mathrm{TW}=$ testicle (width). 
region is hyperechogenic with respect to the medulla (Fig.2). Adrenal glands and ureters were not seen in any animal.

The genital organs were located caudally to the GB and cranially to the kidneys, in the caudal third of the coelomic cavity. In males, the testis were viewed in the longitudinal and transverse plane and characterized as fusiform structures, with regular contours, homogeneous and hypoechoic parenchyma in relation to all structures (Fig.3), however it was not possible to identify them in all animals in the study. No epididymis was observed in any of the animals.

Ovarian follicles were visualized in different stages, in the longitudinal and transversal planes. They were characterized as ovoid structures, with anechoic and hypoechoic content, with homogeneous echotexture, thin, regular and hyperechogenic walls (Fig.3). The pre-vitellogenic follicles were smaller, spherical and anechoic and were seen only in the species E. crassus. Vitellogenic follicles, however, were larger and hyperechoic and were seen in the species $B$. constrictor constrictor and $B$. constrictor amarali. However, it was not possible to visualize the follicles in all females in the study.

\section{DISCUSSION}

For the ultrasonographic exam a layer of water-soluble gel was applied to the scales of all animals, as well as to the transducer in order to minimize the occurrence of artifacts. Artifacts in the study occurred due to gases in the gastrointestinal tract, making visualization and characterization difficult. The main artifacts in the ultrasonographic exam of snakes are the acoustic barrier in the keratin on the scales, the presence of ribs in almost the entire corporal extension, air in the lungs and air sacs, gases
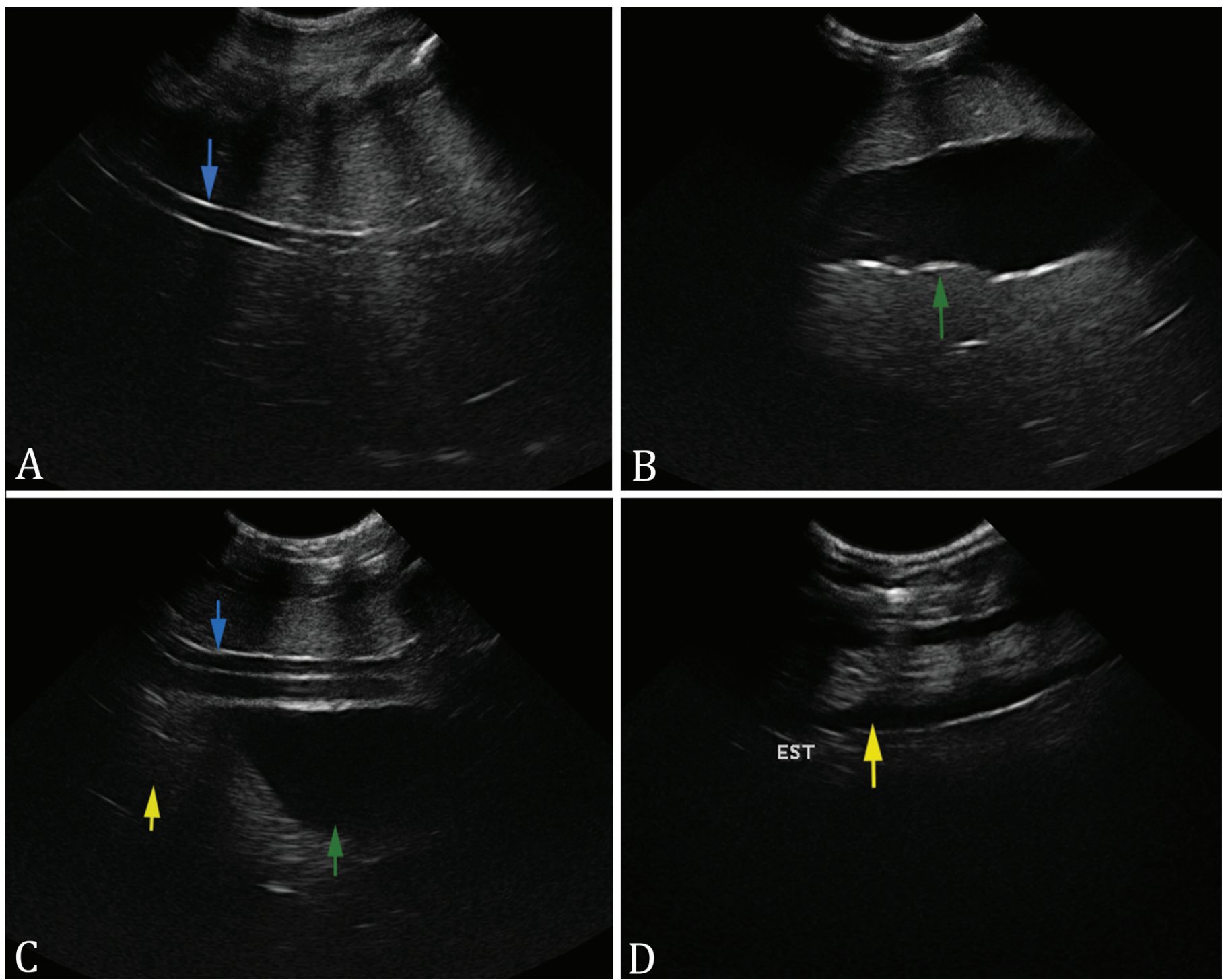

Fig.1. Ultrasonographic images of organs in the coelomic cavity of Eunectes murinus. (A) Bilobulated liver, slightly hyperechoic, homogeneous echotexture, with hyperechogenic capsule and hepatic vein with hyperechoic walls, with anechogenic content (blue arrow). (B) Gallbladder (GB) with anechoic content and thin echogenic wall (green arrow). (C) Stomach represented by the yellow arrow, located dorsal to the liver and hepatic vein (blue arrow) and cranial to GB (green arrow). (D) Stomach with pleated and linear aspect, echogenic, heterogeneous echotexture, with hypoechoic walls (yellow arrow). Source: Diagnostic Imaging Sector at the Veterinary Hospital of the "Universidade Federal de Uberlândia". 


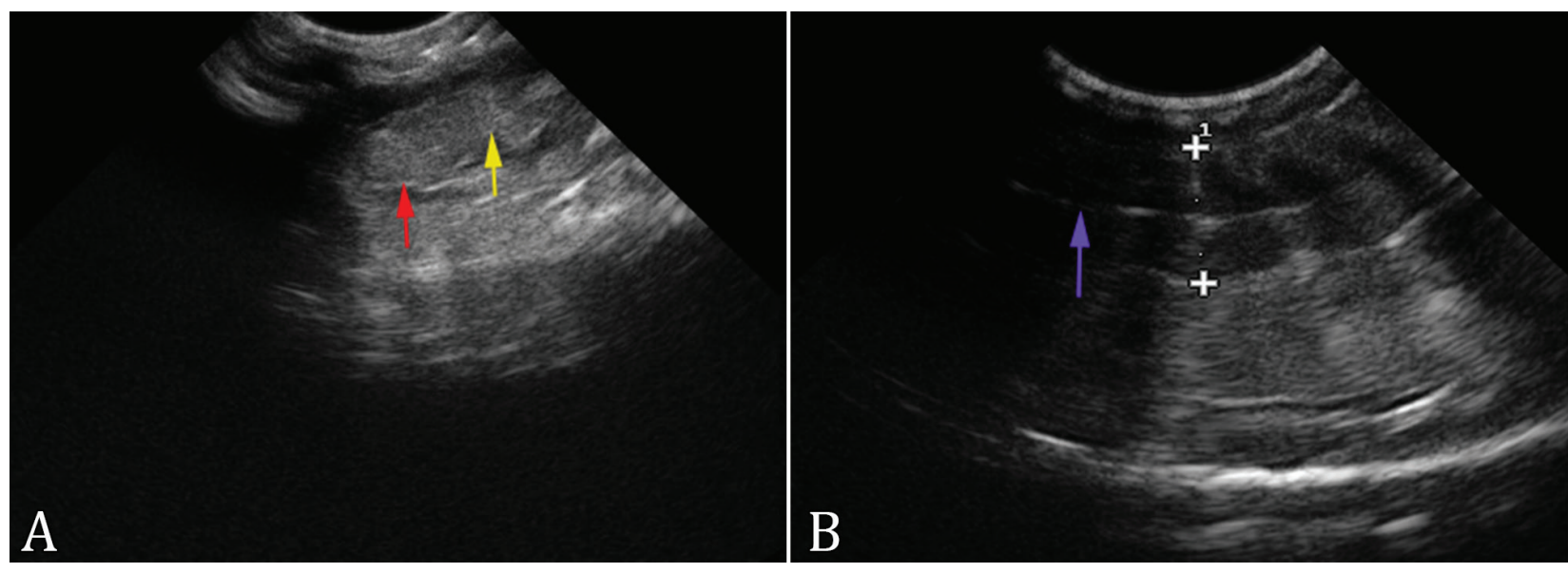

Fig.2. Ultrasonographic image of coelomic organs from Boa constrictor amarali. (A) Spleen is characterized by a circular, small, echogenic structure with homogeneous echotexture (red arrow), while the pancreas is slightly hypoechoic in relation to the spleen with homogeneous echotexture (yellow arrow). (B) Kidney presenting itself as an elongated, lobulated, hypoechoic structure, heterogeneous echotexture, echogenic capsule and an echogenic central line (purple arrow). Source: Diagnostic Imaging Sector at the Veterinary Hospital of the "Universidade Federal de Uberlândia".
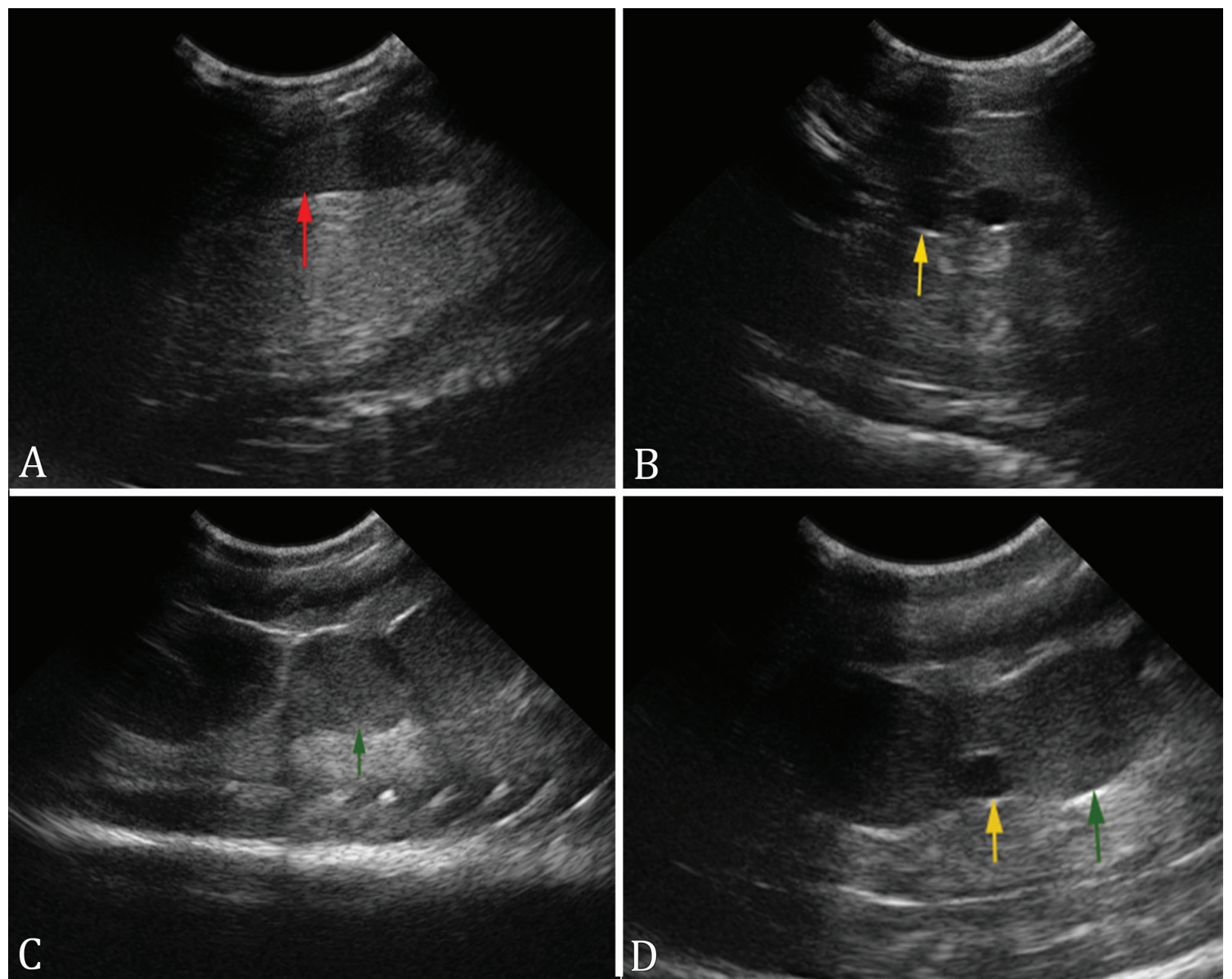

Fig.3. Ultrasound images of genital organs of snakes of the Boidae family. (A) Testicle of Epicrates assisi, with fusiform shape, hypoechoic aspect and homogeneous echotexture (red arrow). (B) Pre-vitellogenic ovarian follicles (anecogenic aspect) of the species Epicrates crassus (yellow arrow). (C) Vitellogenic ovarian follicles (hypoechogenic aspect) of the Boa constrictor constrictor species (green arrow). (D) Vitellogenic follicles (green arrow) and pre-vitellogenic follicle (yellow arrow) in a specimen of the species B. constrictor constrictor. Source: Diagnostic Imaging Sector at the Veterinary Hospital of the "Universidade Federal de Uberlândia". 
on intestinal loops, and interference of underlaying air during ecdysis. All these factors may limit or impede the penetration of ultrasound waves. To minimize the artifacts, it is important to use gel on the scales (Silverman 2013, Stetter 2013).

In the present study the ultrasonographic exam was done with the animal in an anatomical position and the acoustic window was obtained in the frontal plane, without impairing the visualization of the structures and without artifacts. For the ultrasonographic exam, snakes may be kept in anatomical position or may be positioned in dorsal recumbency and the acoustic window may be obtained through the lateral wall or the ventral surface of the coelomic cavity (Jacobson 1993, Raiti 2004). Dorsal recumbency is uncomfortable for animals and, therefore, it is necessary to pharmacologically restrain the animals. Furthermore, the presence of fatty bodies, especially in the ventral portion of the coelomic cavity reduces image quality, particularly in large animals (Banzato et al. 2012). The ultrasonographic access through the lateral wall of the coelomic cavity may result in poor visualization of the internal structures due to the image artifacts caused by the ribs, which did not occur in this study (Isaza et al. 1993).

The ultrasonographic evaluation was done in longitudinal and transversal planes and the scan was done in the craniocaudal direction. The heart was used as a reference point of easy location for the start of the scan of the liver, in the end of cranial third and beginning of the middle third, according to the described in literature (Neto et al. 2009, Andrade et al. 2012). The ultrasonographic evaluation must be done systematically in all organs, starting with the heart and directing the transducer caudally to the liver, stomach, gallbladder, intestines and urogenital tract (Stetter 2013).

The data obtained in the present study corroborates the literature regarding echogenicity and hepatic echotexture. The liver is separated from the heart by the lungs. The liver gradually increases when the transducer moves from the cranial third of the animal to the middle third. The hepatic parenchyma must present well defined contours and echogenicity between hypoechoic and slightly hyperechoic and homogeneous echotexture throughout its extension (Andrade et al. 2012, Stetter 2013).

The hepatic vein was visualized in a longitudinal plane, throughout the entire extension of the hepatic parenchyma, which corroborates Stetter (2013), who describes the presence of a central hepatic vein evident in the liver of snakes, which helps to differentiate the hepatic parenchyma of the fatty tissue. In a study done by Aguisanda et al. (2011) in the species of Python reticulatus, the size of the hepatic parenchyma was $42.22 \pm 1.34 \mathrm{~cm}$ in length and the central hepatic vein measured $37.67 \pm 1.67 \mathrm{~cm}$ in length. In the present study it was not possible to take the hepatic length due to the large extension of the organ.

The gallbladder was visible in all animals and proved to be full and anechoic, however, it was not possible to visualize the bile duct in the anaconda (Ephebopus murinus). The gallbladder is easily identified in individuals smaller than $1.5 \mathrm{~m}$, in larger specimens, it is difficult to identify, due to its mobility, however, such difficulty was not observed in the present study. The bile duct has an anechoic appearance, visible in the hepatic parenchyma of smaller animals, but with difficult visualization (Purdoiu et al. 2016). In Python reticulatus, the gallbladder had an average length of $4.74 \pm 0.79 \mathrm{~cm}$ and an average width of $5.74 \pm 1.34 \mathrm{~cm}$, values similar to those found in the present study (Aguisanda et al. 2011).

The stomach was identified in all animals in the present study, empty or filled with food or gas content, in the region dorsal to the liver and cranial to GB. The gastric wall was $0.3 \pm 0.07 \mathrm{~cm}$ wide. The stomach can be easily identified in snakes, however, the presence of luminal or adjacent gas makes it difficult to characterize the organ (Isaza et al. 1993). The organ was partially visualized in some snakes, starting from the final third of the liver, with hypoechogenic walls (Matayoshi et al. 2012).

In the present study, it was not possible to evaluate the stratification of the gastrointestinal tract. The five layers of the mucosa of the digestive tract, classically described in mammals, are visible only in large reptiles (Wilkinson et al. 2004 , Silverman 2013, Stetter 2013). In one study, the gastric and pyloric walls had two layers, a thin outer echoic layer and an inner anechoic layer. Gastric folds were evidenced in longitudinal and transverse scans, as well as the absence of cardia (Banzato et al. 2012).

The intestine was only visualized in three animals, located caudal to the stomach, in the middle and caudal third of the coelomic cavity and it was not possible to define the contours of the organ in most animals. It corroborates the literature, which mentions that the ultrasound visualization of the intestinal loops is extremely difficult due to the presence of gases, feces or food content in its lumen (Redrobe \& Wilkinson 2002, Raiti 2004). The small intestine can be mistaken for large vessels. It is necessary to use Doppler for differentiation, however, in mode B it was possible to visualize intestinal motility (Purdoiu et al. 2016).

In the present study, it was not possible to view the splenopancreas in all animals. According to the literature, the spleen and pancreas are difficult to locate and visible on ultrasound examination, in most species of reptiles (Schildger et al. 1994). The identification and positioning of the splenopancreas depend on variables such as the degree of gallbladder repletion and the development of ovarian follicles (Andrade et al. 2012). The python spleen had an average diameter of $3.33 \pm 0.39 \mathrm{~cm}$, higher than those found in the present study, possibly due to the difference between the species studied, size and body mass (Aguisanda et al. 2011).

Stetter (2013) reported difficulty in identifying reptile kidneys by ultrasound examination. In the present study, the organ was easily seen in the larger species, however, it was more difficult to identify in the smaller species (Epicrates crassus), and it was not possible to view it in all animals. In snakes, the kidneys are usually located in the caudal third of coelomic cavity, the right being more cranial than the left. The kidneys can be seen in association with fatty bodies of snakes, which was also observed in larger species (Andrade et al. 2012).

The results obtained in the present study regarding ovarian follicles corroborate the literature. The pre-vitellogenic follicles were smaller, spherical and anechoic, measuring $0.4 \times 0.36 \mathrm{~cm}$ and $0.37 \times 0.35 \mathrm{~cm}$ in diameter. Vitellogenic follicles, on the other hand, were larger and hyperechoic, with $1.18 \times 1.11 \mathrm{~cm}$ dimension and $1.02 \times 0.81 \mathrm{~cm}$ in diameter. In females, regardless of the season, ovarian follicles are easily identified, which did not occur in the present study, performed outside the breeding season (Stetter 2013). 
According to Garcia et al. (2015), the pre-vitellogenic follicles can be recognized as small grouped spheres, in the form of a "grape bunch", anechogenic or hypoechogenic, and homogeneous, measuring $0.40 \times 2.50 \mathrm{~cm}$, values above that found in the present study. The authors described the vitellogenic follicles as larger and hyperechogenic following each other, in the form of a "pearl necklace", with a dimension of $1.60 \times 5.70 \mathrm{~cm}$, being greater values than those found in this study.

The present study was not carried out in breeding season, which may have made it difficult to visualize the testis and resulted in greater variations in the dimensions of the organs. The mating season of boidae is different between species in captivity, possibly due to the climatic differences where they are kept. However, in general, females of boidae show vitellogenesis concentrated in autumn-winter (Prado, 2006).

According to Garcia et al. (2015), in the reproductive season, the testis are symmetrical, have regular and defined contours, homogeneous parenchyma, measuring $6.20 \mathrm{~cm}$ in length in E. murinus, $8.70 \mathrm{~cm}$ in Boa constrictor constrictor and $6.10 \mathrm{~cm}$ in Epicrates cenchria, values above those found in the males in the study. In the non-reproductive period, the organs had smaller dimensions or were not seen. According to Stetter (2013), during the non-reproductive season, the testis usually regress. At the beginning of the reproductive season, the gonads increase in size, becoming more apparent. Some authors have described the presence of an epididymis in snakes (Langlada et al. 1994), but in the study by DeNardo (2006) this structure was not observed, which corroborates the data obtained.

\section{CONCLUSIONS}

The ultrasound evaluation of the celomic cavity of snakes can be easily performed and used as a complementary exam in the diagnosis of diseases.

The evaluation of healthy snakes of the Boidae family allowed the characterization of organs and obtaining measures to establish normality parameters. The syntopy, echogenicity and ecotexture of the organs did not vary according to the different species, only the measurement values of the organs, due to the difference in mass and body size between them.

Conflict of interest statement.- The authors have no competing interests.

\section{REFERENCES}

Aguisanda S.T., Lastica E.A. \& Acorda J.A. 2011. Ultrasonographic features of the liver, gall bladder and spleen of captive reticulated pythons (Python reticulatus). Philipp. J. Vet. Anim. Sci. 37(2):177-186.

Andrade R.S., Monteiro F.O.B., Ribeiro A.S.S., Ruffeil L.A.A.S. \& Castro P.H.G. 2012. Anatomia ultrassonográfica de fígado, baço e trato urogenital em jiboias. Revta Ciênc. Agrárias 55(1):66-73. <https://dx.doi.org/10.4322/ rca.2012.036>

Augusto A.Q. \& Hildebrandt T.B. 2014. Ultrassonografia, p.1706-1720. In: Cubas Z.S., Silva J.C.R. \& Catão-Dias J.L. (Eds), Tratado de Animais Selvagens. $2^{\mathrm{a}}$ ed. Roca, São Paulo.

Banzato T., Russo E., Finotti L., Milan M.C., Gianesella M. \& Zotti A. 2012. Ultrasonographic anatomy of the coelomic organs of boid snakes (Boa constrictor imperator, Python regius, Python molurus molurus, Python curtus). Am. J. Vet. Res. 73(5):634-645. <https://dx.doi.org/10.2460/ ajvr.73.5.634><PMid:22533394>
Bortolini Z., Lehmkuhl L.M., Ozeki M.V., Tranquilim N.F., Sesoko C.R. \& Teixeira L.C. 2012. Association of 3D and conventional radiography for the description of the apendicular skeleton of Chelonoidis carbonaria (Spix, 1824). Anat. Histol. Embryol. 41(6):445-452. <https://dx.doi. org/10.1111/j.1439-0264.2012.01155.x>

Bortolini Z., Matayoshi P.M., Santos R.V., Doiche D.P., Machado V.M.V., Teixeira C.R. \& Vulcano L.C. 2013. Casuística dos exames de diagnóstico por imagem na medicina de animais selvagens - 2009 a 2010. Arq. Bras. Med. Vet.Zootec, 65(4):1247-1252.<https://doi.org/10.1590/S0102-09352013000400042>

Denardo D. 2006. Reproductive biology, p.376-390. In: Mader D.R. (Ed.), Reptile Medicine and Surgery. W.B. Saunders, Philadelphia.

Garcia V.C., Vac M.H., Badiglian L. \& Almeida-Santos S.M. 2015. Avaliação ultrassonográfica do aparelho reprodutor em serpentes vivíparas da família Boidae. Pesq. Vet. Bras. 35(3):311-318. <https://dx.doi.org/10.1590/ S0100-736X2015000300016>

Isaza R., Ackerman N. \& Jacobson E.R. 1993. Ultrasound imaging of the coelomic structures in the (Boa constrictor). Vet. Radiol. Ultrasound 34(6):445-450. <https://dx.doi.org/10.1111/j.1740-8261.1993.tb02034.x>

Jacobson E.J. 1993. Snakes. Vet. Clin. N. Am., Small Anim. Pract. 23(6):11791212. <https://dx.doi.org/10.1016/S0195-5616(93)50152-3>

Langlada F.G., Santos S., \& Ferreira I.L.L. 1994. Techniques of artificial insemination in Crotalus durissus terrificus (Viperidae-Crotalinae). Braz. J. Vet. Res. Anim. Sci. 31(2):141-144. <https://dx.doi.org/10.11606/ issn.1678-4456.bjvras.1994.52059>

Matayoshi P.M., Souza P.M. \& Júnior R.S.F. 2012. Avaliação ultrassonográfica da cavidade celomática de serpentes. Vet. Zootec. 19(4):448-459.

Muzzi L.A.L., Muzzi R.A.L. \& Rezende C.M.F. 2001. Ultrasonografia da articulação fêmoro-tíbio-patelar em cães normais. Ciênc. Anim. 11(1):209.

Neto F.C., Guerra P.C., Costa F.B., Araújo A.V., Miglino M.A., Bombonato P.P., Vulcano L.C. \& Alves F.R. 2009. Ultra-sonografia do fígado, aparelho renal e reprodutivo da jiboia (Boa constrictor). Pesq. Vet. Bras. 29(4):317-321. <https://dx.doi.org/10.1590/S0100-736X2009000400007>

Oliveira M.E.F., Feliciano M.A.R. \& Oliveira L.G. 2013. Ultrassonografia na reprodução, p.305-345. In: Ibid. (Eds), Biotécnicas Reprodutivas em Ovinos e Caprinos. Med Vet, São Paulo.

Prado L.P. 2006. Ecomorfologia e estratégias reprodutivas nos Boidae (serpentes), com ênfase nas espécies neotropicais. Doctoral Dissertation in Ecology, Universidade Estadual de Campinas, Instituto de Biologia, Campinas. 151p.

Purdoiu R.C., Bel L., Lăcătuș R. \& Papuc I. 2016. Ultrasonographic aspect of coelomic organs in boid snakes. Bull. UASVM Vet. Med. 73(1):176-181. <https://dx.doi.org/10.15835/buasvmcn-vm:11962>

Raiti P. 2004. Non-invasive imaging, p.87-102. In: Girling S.J. \& Raiti P. (Eds), BSAVA Manual of Reptiles. Blackwell Publishing, Cheltenham.

Redrobe S. \& Wilkinson R.J. 2002. Reptile and amphibiam anatomy and imaging, p.193-207. In: Redrobe S. \& Meredith A. (Eds), Manual of Exotic Pets. Grafos, Barcelona.

Schildger B., Casares M. \& Kramer M. 1994. Technique of ultrasonography in lizards, snakes and chelonians. Semin. Avian Exot. Pet Med. 3:147-155.

Silverman S. 2013. Diagnostic imaging, p.471-489. In: Mader D.R. (Ed.), Reptile Medicine and Surgery. Saunders Elsevier, St Louis.

Stetter M.D. 2013. Ultrasonography, p.665-674. In: Mader D.R. (Ed.), Reptile Medicine and Surgery. W.B. Saunders, Philadelphia.

Wilkinson R.S., Hernandez-Divers M., Lafortune M., Calvert I., Gumpenberger M. \& McArthur S. 2004. Diagnostic imaging techniques, p.187-238. In: McArthur S., Wilkinson R. \& Meyer J. (Eds), Medicine and Surgery of Tortoises and Turtles. Blackwell Publishing, Oxford. 